\title{
Mechanism of LH Release in Cultured Rat Pituitary Cells
}

\author{
Toshihiko IIDA, Tsunehisa MAKINO, TAKashi SEKI \\ AND RIHACHI IIZUKA \\ Department of Obstetrics and Gynecology, School of Medicine, \\ Keio University, Shinjuku-ku, Tokyo 160, Japan
}

\begin{abstract}
To investigate the mechanisms of the synthesis and the release of gonadotropin, rat anterior pituitary cells were stimulated in vitro with luteinizing hormone releasing hormone $(\mathrm{LH}-\mathrm{RH}),[\mathrm{D}-\mathrm{Ser}(\mathrm{tBu})]^{6}$ des-Gly- $\mathrm{NH}_{2}^{10}$ ethylamide (Buserelin) and 12-0-tetradecanoyl phorbol-13-acetate (TPA), and then the LH and LH- $\beta$ subunit released into the medium were determined by radioimmunoassay. Buserelin showed its biological activity at a much lower concentration than LH-RH, but both of them caused the release of LH and LH- $\beta$ subunit in a dose-dependent manner. Furthermore, intracellular LH synthesis from LH- $\beta$ subunit by stimulation with LH-RH or Buserelin was also found. After inducing (various "degrees of desensitization by stimulation with LH-RH or Buserelin in a dose-dependent manner (the first stimulation), pituitary cells were stimulated with a fixed dose of TPA (the second stimulation) and the released LH was assayed. LH was released almost constantly by the second stimulation, regardless of the dose used for the first stimulation. These results suggest that the $C$-kinase pathway was unaffected by the desensitization induced with LH-RH or Buserelin.
\end{abstract}

Numerous studies have been performed concerning the mechanism of release of gonadotropins from pituitary cells in response to stimulation with luteinizing hormone releasing hormone (LH-RH). Nevertheless, many points still remain to be elucidated. The present study was designed to investigate the mechanism of the synthesis and the release of $\mathrm{LH}$ and the desensitization phenomenon in rat anterior pituitary cells by using LH-RH

Received June 29, 1989

Address: The Endocrinology and Reproduction Research Branch National Institute of Child Health and Human Development Building 10, Room 8C-407 Bethesda, Maryland 20892, U.S.A. and its agonist, [D-ser $(\mathrm{tBu})]^{6}$ des-Gly- $\mathrm{NH}_{2}^{10}$ ethylamide (Buserelin). It is well-known that luteinizing hormone (LH) consists of two subunits, i.e., an $\alpha$-subunit and a $\beta$ subunit. Especially the $\beta$-subunit possesses the biological activity of $\mathrm{LH}^{8)}$. To examine whether the LH- $\beta$ subunit can be converted into $\mathrm{LH}$ by exogenous stimulation, the pituitary cells were stimulated with LH$\mathrm{RH}$ or Buserelin and the intracellular and the extracellular $\mathrm{LH}$ and $\mathrm{LH}-\beta$ subunit concentrations were determined. Many investigators have described the phenomenon of desensitization which occurs when pituitary cells are continuously stimulated with a secretagogue and fail to respond 
by releasing $\mathrm{LH}^{5)}$. However, the mechanism of LH desensitization has not been sufficiently elucidated, although down-regulation of $\mathrm{LH}-\mathrm{RH}$ receptors has been suggested as one of the causes of desensitization ${ }^{6)}$. In this study, the influence of desensitization induced by LH-RH on the C-kinase pathway was investigated by using 12-0-tetradecanoyl phorbol-13-acetate (TPA) which activates C-kinase without mediation by LH-RH receptors ${ }^{4)}$.

\section{Materials and Methods}

\section{Cell dispersion and Culture}

Pituitary cell dispersion was performed by a modification of the method of Vale et $a l^{10)}$. Sprague-Dawley rats weighing about 200-250 g were killed by decapitation at a low temperature using dry ice, and only the anterior lobes of the pituitary were removed for culture. The whole pituitary was collected into sterile $25 \mathrm{mM}$ HEPES-buffered Medium 199 (Gibco) containing $0.3 \%$ BSA (fraction V, Sigma) and minced into $0.5-\mathrm{mm}^{3}$ cubes. After washing the pituitary pieces twice with Medium 199/BSA, a prepared solution of $25 \mathrm{mg}$ of Trypsin (Sigma) $/ 5 \mathrm{ml}$ of Medium 199 was added, and the suspension was incubated for 15 minutes at $37^{\circ} \mathrm{C}$. The pieces were reincubated with $10 \mu \mathrm{g}$ of deoxyribonuclease (Sigma, type 1) $/ 5 \mathrm{ml}$ of Medium 199 for 1 minute, and the reaction was terminated by incubation with $10 \mathrm{mg}$ of trypsin inhibitor (Sigma) $/ 5 \mathrm{ml}$ of Medium 199. After chelation by treating with $2 \mathrm{mM}$ EDTA for 5 minutes and $1 \mathrm{mM}$ EDTA for 15 minutes and decantation, the pieces were suspended in Dulbecco's PBS which was adjusted to $\mathrm{pH} 7.3$ and contained $0.3 \% \mathrm{BSA}$ and $50 \mathrm{U} / \mathrm{ml}$ penicillin and $50 \mu \mathrm{g} / \mathrm{ml}$ streptomycin without $\mathrm{Ca}^{2+}$ and $\mathrm{Mg}^{2+}$. The pieces were then thoroughly dispersed into cells by inverting the test tube gently several times and pipetting. The dispersed pituitary cells were centrifuged at $470 \times \mathrm{g}$ for 5 minutes and resuspended in culture medium (Medium 199 adjusted to $\mathrm{pH} 7.3$, containing $25 \mathrm{mM}$ Hepes, $10 \%$ horse serum, $50 \mathrm{U} / \mathrm{ml}$ penicillin and $50 \mu \mathrm{g} /$ $\mathrm{ml}$ streptomycin). Finally the cells were dispensed into the wells of a multiwell culture plate (Corning) at a density of $2 \times 10^{5}$ cells per dish and preincubated for 72 hours at $37^{\circ} \mathrm{C}$ under atmosphere of $5 \% \mathrm{CO}_{2}$ in air.

\section{$L H$ and $L H-\beta$ subunit release in response to $\mathrm{LH}-\mathrm{RH}$ and Buserelin}

After the preincubation, the pituitary cells were washed twice with fresh culture medium and stimulated with $10^{-11} \mathrm{M}-10^{-7} \mathrm{M}$ of either LH-RH or Buserelin for 3 hours. The amount of $\mathrm{LH}$ and $\mathrm{LH}-\beta$ subunit released into the medium and contained in the cell was determined by radioimmunoassay. After the preincubation and changing of the culture medium, other pituitary cells were incubated with either $10^{-8} \mathrm{M}$ LH-RH or $10^{-8} \mathrm{M}$ Buserelin for $0,7,5$, $30,60,120,180$ and 240 minutes for a timecourse study and the $\mathrm{LH}$ released into the medium was assayed.

\section{Desensitization induced by LH-RH and Buserelin}

Pituitary cells were incubated with $10^{-11} \mathrm{M}$ $10^{-7} \mathrm{M}$ of LH-RH for 3 hours (the first stimulation) after the preincubation, and the released LH was assayed. After washing with the fresh medium, these stimulated cells were incubated again with $10^{-7} \mathrm{M}$ of $\mathrm{LH}-\mathrm{RH}$ or $10^{-7} \mathrm{M}$ of TPA for 3 hours (the second stimulation), and an aliquot of each medium was kept for determination of LH. In the stimulation with Buserelin substituted for LH-RH, the same procedure was adopted. Preincubated pituitary cells were exposed to the first stimulation with $10^{-11} \mathrm{M}-10^{-7} \mathrm{M}$ of Buserelin and then the second stimulation with $10^{-7} \mathrm{M}$ of Buserelin or $10^{-7} \mathrm{M}$ of TPA; each aliquot of medium was kept for LH quontitation.

\section{Assay of $\mathrm{LH}$ and $\mathrm{LH}-\beta$ subunit}

For the assay of the cell content of LH and LH- $\beta$ subunit, the pituitary cells were washed twice with fresh medium, and complete cell lysis induced by adding $0.1 \mathrm{~N} \mathrm{HCl}$ and subsequently neutralized with $0.1 \mathrm{~N} \mathrm{NaOH}$. Aliquots of the solution containing efflux of the cell content were kept for the determination of $\mathrm{LH}$ and LH- $\beta$ subunit. For the determination of the LH and the LH- $\beta$ subunit concentration, radioimmunoassay by the double antibody method was employed. The antiserum and standard hormone reagents were kindly provided by the Pituitary Hormone Distribution Program, NIADDKD (National Institute of Arthritis, 
Diabetes and Digestive and Kidney Diseases), U.S.A. The standards used in this study were NIAMDD-rLH-RP2 for rat $\mathrm{LH}$ and AFP-A805 for $\mathrm{LH}-\beta$ subunit.

\section{Statistical analysis}

Each sample was tested in triplicate and the data are expressed as the means showing the standard error $(n=3)$. Student's $t$-test was employed for statistical analysis and the significant difference was determined at the level of $\mathbf{P}<0.05$.

\section{Results}

\section{$\mathrm{LH}$ release in response to $\mathrm{LH}-\mathrm{RH}$ and Buserelin}

As shown in Fig. 1, LH was released by LH-RH in a dose-dependent manner, and its increase was significant from $10^{-10}$ $\mathrm{M}$ of LH-RH compared with the control $(\mathrm{P}<0.01)$. As LH released into the medium

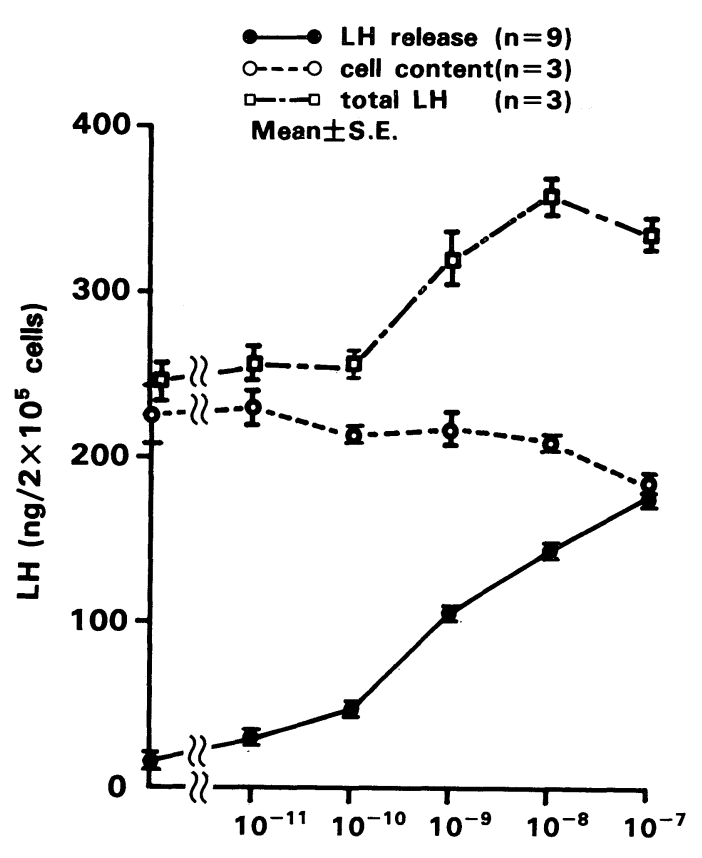

LH-RH concentration (M)

Fig. 1. LH release and cell content of $\mathrm{LH}$ in response to LH-RH after 3 hours of incubation. increased, the cell content of LH showed a tendency to decline gradually, and it was significantly decreased at $10^{-7} \mathrm{M}$ of $\mathrm{LH}-\mathrm{RH}$ compared with the control $(\mathrm{P}<0.01)$. The total amount of intracellular and released LH began to increase at an LH-RH concentration of $10^{-9} \mathrm{M}$, and showed a $46 \%$ increase at $10^{-8} \mathrm{M}$ compared with the control. As shown in Fig. 2, similar results were obtained by stimulating with Buserelin. LH was released in a dose-dependent manner by Buserelin, but the cell content of $\mathrm{LH}$ at $10^{-11} \mathrm{M}$ of Buserelin was significantly lower than in the control $(\mathrm{P}<0.01)$. In contrast, the total LH was $19.2 \%$ higher than the control. Since $10^{-11} \mathrm{M}$ of Buserelin released $80 \%$ of the maximum concentration of $\mathrm{LH}$ and $10^{-10} \mathrm{M}$ of Buserelin released $91 \%$ of it, Buserelin showed the characteristic of being able to express biological activity at a lower concentration than LH-RH. Fig.

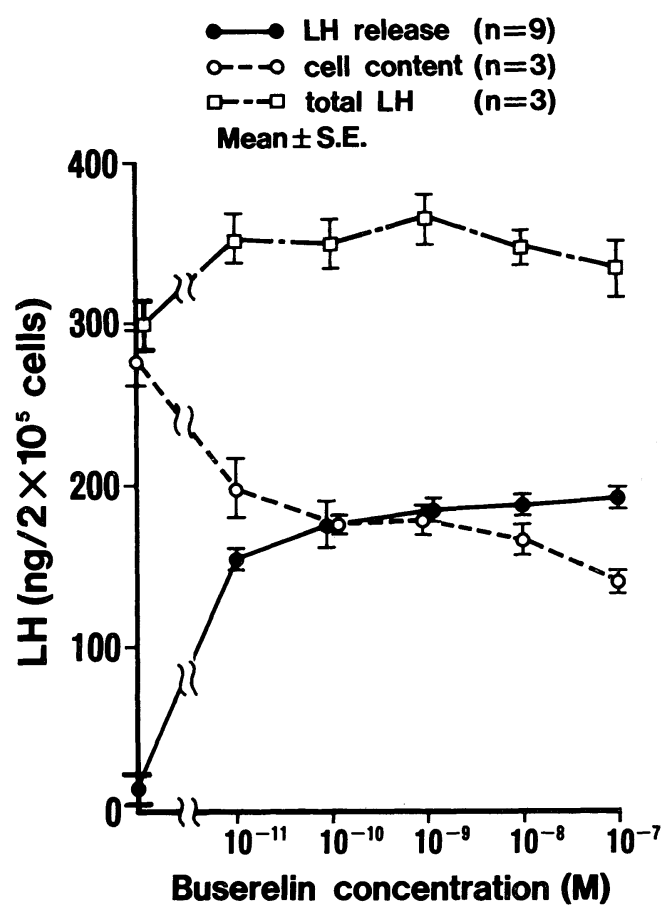

Fig. 2. LH release and cell content of $\mathrm{LH}$ in response to Buserelin after 3 hours of incubation. 


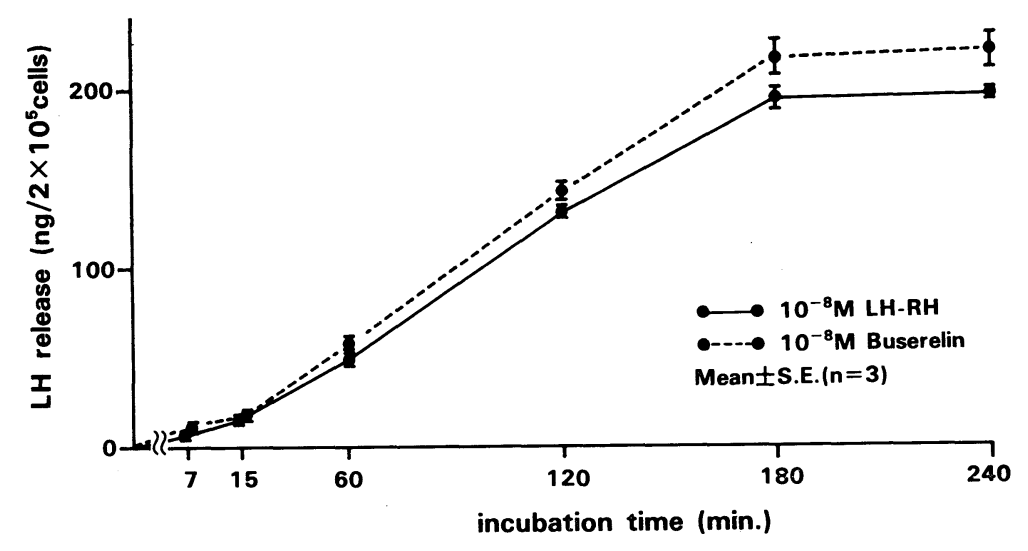

Fig. 3. Time-courses of $\mathrm{LH}$ release in response to LH-RH and Buserelin.

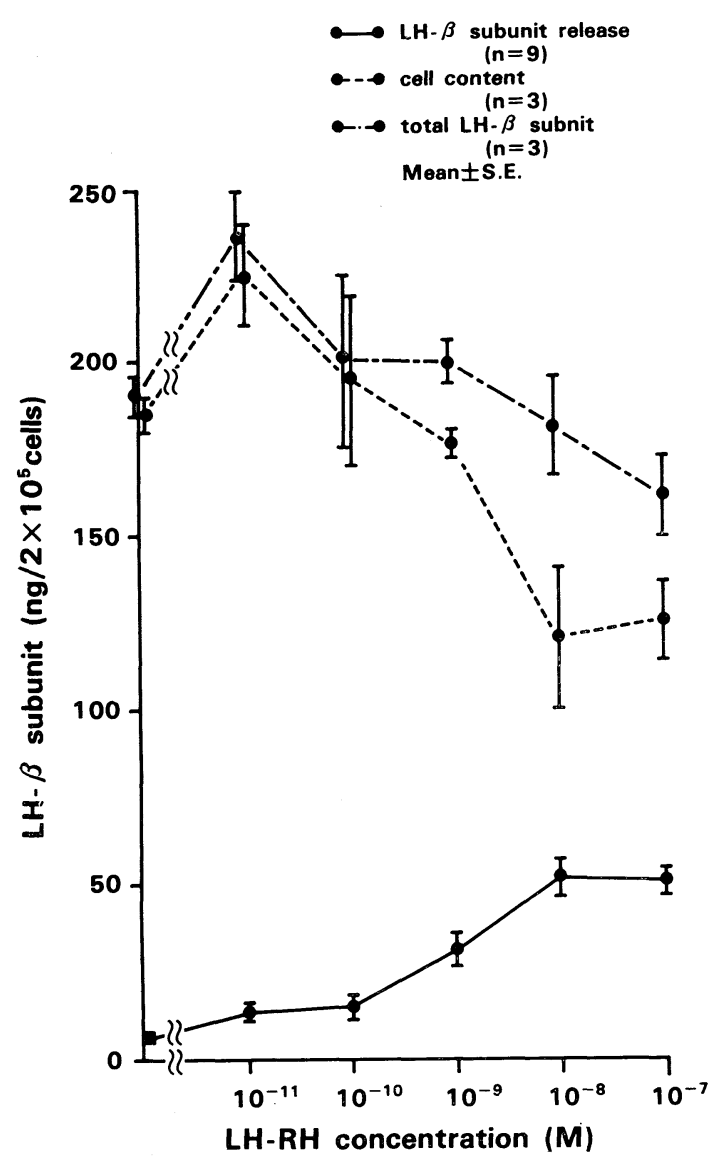

Fig. 4. Release and cell content of LH- $\beta$ subunits in response to LH-RH after 3 hours of incubation.
3 shows that LH-RH and Buserelin had similar time-courses activity. The released LH increased along with the incubation time and reached a plateau after 180 minutes with both secretagogues. No significant differences were found in their time-course patterns except for a slightly larger increase in $\mathrm{LH}$ release by Buserelin than by LH-RH at 240 minutes $(\mathrm{P}<0.05)$.

\section{LH- $\beta$ subunit release in response to LH-RH and Buserelin}

As shown in Fig. 4 the pattern of release of the LH- $\beta$ subunit in response to LH-RH was similar to the pattern of LH release. This dose-response pattern showed a significant increase at $10^{-9} \mathrm{M}$ of $\mathrm{LH}-\mathrm{RH}$ compared with the control $(\mathrm{P}<0.05)$. Like the release of $\mathrm{LH}$, as the release of the LH- $\beta$ subunit increased, its cell content showed a tendency to decline and significantly decreased by $31.4 \%$ at $10^{-7} \mathrm{M}$ of LH-RH compared with the control. However, it is interesting that the total amount of LH was significantly increased, whereas the total amount of the LH- $\beta$ subunit was significantly decreased, showing a $15 \%$ decrease at $10^{-7} \mathrm{M}$ compared with the control.

With the stimulation by Buserelin, the $\mathrm{LH}-\beta$ subunit was also released in a dose- 
dependent manner, showing a significant increase at $10^{-11} \mathrm{M}$ and reaching a plateau at $10^{-9} \mathrm{M}$ (Fig. 5). When the LH- $\beta$ subunit was released, its cell content declined, showing a $66.7 \%$ decrease at $10^{-7} \mathrm{M}$ compared with the control. The total (i.e. released plus intracellular) amount of $\mathrm{LH}-\beta$ subunit showed a $37.8 \%$ decrease at $10^{-7} \mathrm{M}$ compared with the control.

\section{Desensitization induced by $\mathrm{LH}-\mathrm{RH}$ and Buserelin}

When pituitary cells were exposed to the first stimulation with LH-RH and to the subsequent second stimulation with the same secretagogue, the amount of $\mathrm{LH}$ released by the second stimulation was decreased compared to the control in inverse proportion to the dose used in the first LHRH stimulation $(\mathrm{P}<0.01)$, as demonstrated in Fig. 6. However, when the cells were stimulated with a fixed dose of TPA as the second stimulant, the amount of $\mathrm{LH}$ released almost unchanged. LH released by the

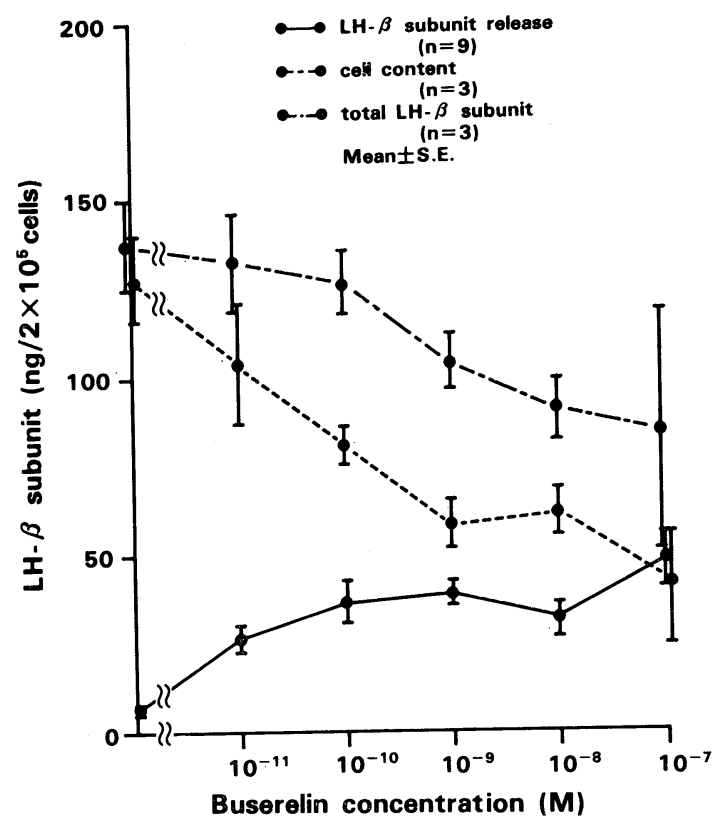

Fig. 5. Release and cell content of LH- $\beta$ subunits in response to Buserelin after 3 hours of incubation.

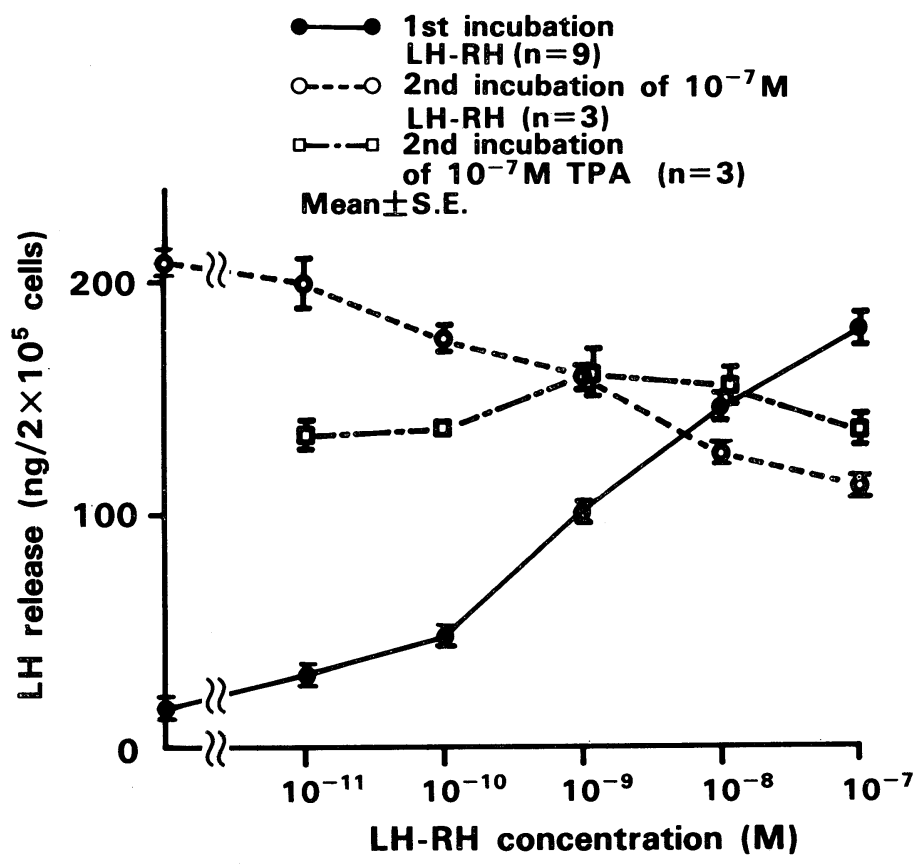

Fig. 6. Effect of LH-RH or TPA on subsequent LH release in pituitary cells desensitized with LH-RH. 


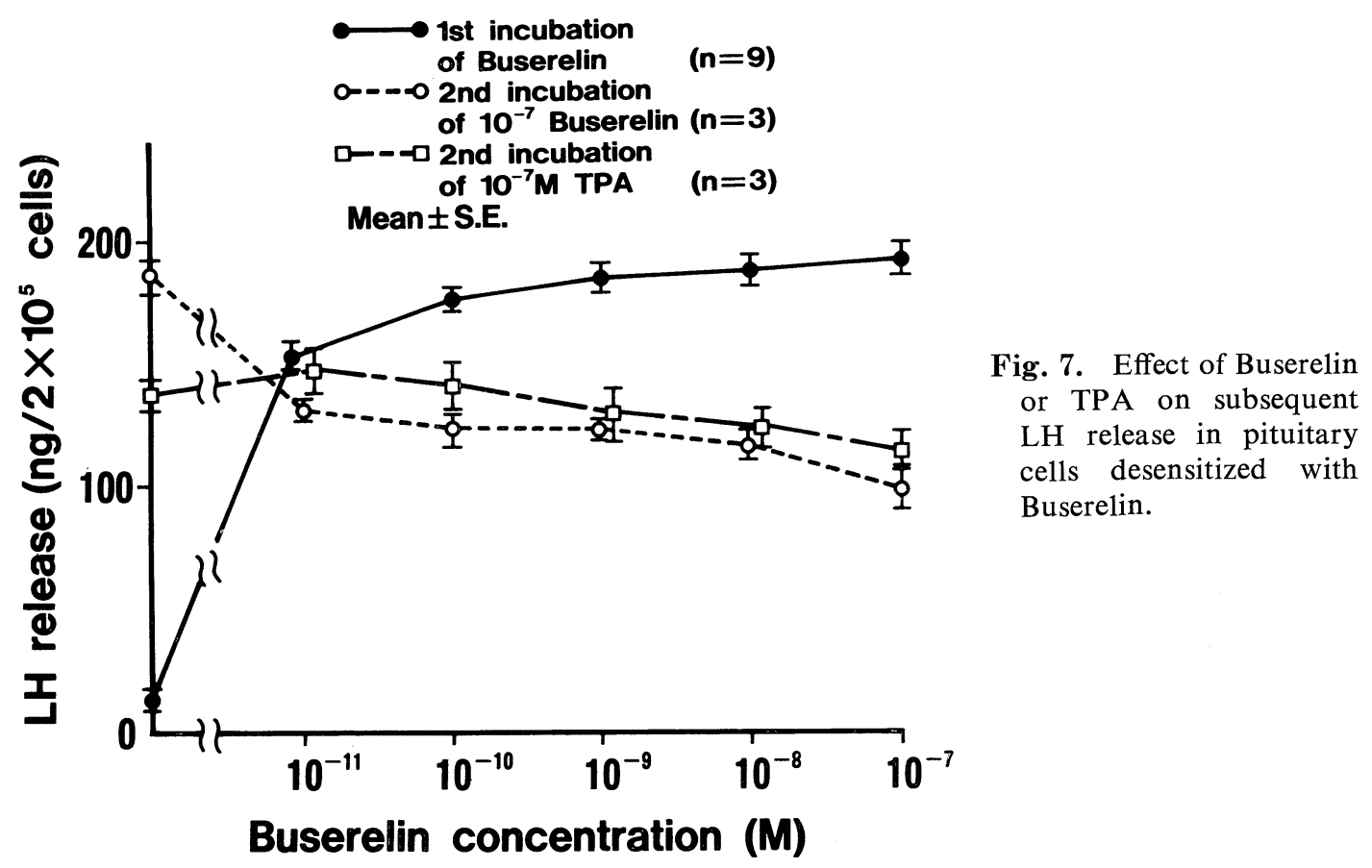

second stimulation with Buserelin from pituitary cells previously stimulated with $10^{-11} \mathrm{M}$ Buserelin was significantly decreased compared with the control $(\mathrm{P}<0.01$; Fig. 7). However, when pituitary cells were stimulated secondarily with the fixed dose of TPA, LH release remained unchanged, as in the LH-RH-stimulation experiment.

\section{Discussion}

It was previously reported that Buserelin had 30-60 times the biological activity of native LH-RH due to its resistance to metabolism in pituitary cytosol and its high affinity for the LH-RH receptors ${ }^{2)}$. In this study Buserelin showed its biological activity from a much lower concentration than $\mathrm{LH}$ $\mathrm{RH}$ in a comparison of their dose-response curves, although the quantity of LH released during a certain period of incubation was almost the same as both secretagogues in the same length of time.

As the LH release from pituitary cells by stimulating with $\mathrm{LH}-\mathrm{RH}$ increased in a dose-dependent manner, the cell content of LH gradually decreased. If the released LH was derived only from intracellular $\mathrm{LH}$ which was already synthesized and new LH synthesis failed to occur in response to the exogenous LH-RH stimulation, the total amount of intra- and extracellular LH would not be changed. Our present study demonstrated that the total amount of $\mathrm{LH}$ increased by $46 \%$ over the control. A similar result was obtained by the stimulation with Buserelin. This suggests that following the stimulation with both LH-RH and Buserelin, LH synthesis in pituitary cells as well as its release occurred. A recent report described how amino-acids in pituitary cells could be converted into $\mathrm{LH}$ by exogenous LH-RH stimulation ${ }^{9)}$. To prove our hypothesis that pituitary LH can probably be converted not only from free amino-acids 
but also from LH-subunits, changes in the manner of the release and the cell content of $\mathrm{LH}-\beta$ subunits in response to $\mathrm{LH}-\mathrm{RH}$ and Buserelin were investigated. Like $\mathrm{LH}$, LH- $\beta$ subunits were released in a dosedependent manner by exogenous LH-RH, and the intracellular content of $\mathrm{LH}-\beta$ subunits decreased along with the LH release. However, the total amount of $\mathrm{LH}$ $\beta$ subunits was significantly decreased, although the total amount of $\mathrm{LH}$ was not decreased. This fact implies that LH- $\beta$ subunits are released into the extracellular space without any modification, but some subunits can also be transformed into LH. Similar results were obtained by stimulating with Buserelin substituted for LH-RH. When pituitary cells were stimulated with various doses of LH-RH or Buserelin and then further stimulated with a fixed dose of the same secretagogues, since pituitary cells were desensitized by the first stimulation, $\mathrm{LH}$ release in response to the second stimulation was decreased. However LH released by the stimulation with a fixed dose of TPA as the second stimulant was almost constant. This implies that TPA activated C-kinase and released $\mathrm{LH}$, regardless of the degree of desensitization induced by either LH-RH or Buserelin. $\mathrm{LH}$ release by $\mathrm{LH}-\mathrm{RH}$ is mediated through the binding of $\mathrm{LH}-\mathrm{RH}$ to $\mathrm{LH}-\mathrm{RH}$ receptors on the cell surface and subsequent stimulation of the cyclic AMP pathway, $\mathrm{Ca}^{++}$ calmodulin and $\mathrm{C}$-kinase pathway, but $\mathrm{LH}$ release by TPA can be induced through direct stimulation of the $\mathrm{C}$-kinase pathway without any binding to $\mathrm{LH}-\mathrm{RH}$ receptors ${ }^{4)}$, 7). Although details of the mechanism of desensitization have not yet been thoroughly elucidated, a decrease in the number of receptors i.e., down regulation, has been reported $^{1), 3)}$. Therefore, even when desensitization is induced by down regulation which is accompanied by stimulation with LH-RH or Buserelin, TPA can release LH without the participation of the LH-RH receptor-mediated pathway. Although the mechanism of pituitary desensitization by LH-RH cannot be concluded to be only a down-regulation mechanism and some other changes can be induced in the post receptor mechanism, our present study demonstrated that the C-kinase pathway was preserved during this desensitization induced by LH$\mathrm{RH}$ or Buserelin.

\section{Acknowledgement}

The authors wish to thank Dr. Katsumi Wakabayashi of the Endocrinological Institute of Gumma University for generously supplying the second antibody for radioimmunoassays in this study. Rat LH, LH- $\beta$ subunit kits were kindly provided by the Pituitary Hormone Distribution Program, National Institute of Arthritis, Diabetes and Digestive and Kidney Diseases, U.S.A. We also wish to thank Ms. Hiroko Otsuka for her assistance throughout this study.

\section{References}

1) Badger, T. M., J. S. Loughlin and P. G. Naddaff (1983). The luteinizing hormonereleasing hormone (LHRH)-desensitized rat pituitary: luteinizing hormone responsiveness to LHRH in vitro. The Endocrine Society. 112 (3), 793-799.

2) Clayton, R. N. et al. (1979). Radioiodinated nondegradable gonadotropin-releasing hormone analogs: new probes for the investigation of pituitary gonadotropin-releasing hormone receptors. The Endocrine Society. 105 (6), 13691376.

3) Conn, P. M., D. C. Rogers and S. G. Seay (1983). Biphasic regulation of the gonadotropin-releasing hormone receptor by receptor microaggregation and intracellular $\mathrm{Ca}^{2 \div}$ levels. Molecular Pharmacology. 25, 51-55.

4) Hirota, K. et al. (1986). Gonadotropin release and redistribution of calcium-activated, phospholipid-dependent protein kinase in phorbol-stimulated rat pituitary cells. Archives Biochemistry Biophysiology. 249, 557-562.

5) Keri, G. et al. (1983). Desensitization of luteinizing hormone release in cultured pitui- 
tary cells by gonadotropin-releasing hormone. Molecular and Cellular Endocrinology. 30, 109-120.

6) Loumaye, E. and K. J. Catt (1983). Agonistinduced regulation of pituitary receptors for gonadotropin-releasing hormone. The Journal of Biological Chemistry. 258 (19), 1200212009.

7) Nishizuka, Y. (1986). The role of protein kinase $\mathrm{C}$ in cell surface signal transduction and tumor promotion. Nature 308, 693-698.

8) Seki, T. et al. (1986). Secretion of the $\beta$ - subunit of luteinizing hormone in dispersed rat anterior pituitary cells. Asia-Oseania $J$. Obstet. Gynecol. 12, 113-118.

9) Starzec, A., R. Counis and M. Jutsz (1986). Gonadotropin-releasing hormone stimulates the synthesis of the polypeptide chains of luteinizing hormone. Endocrinology 119, 561565.

10) Vale, W. et al. (1972). Culture of enzymatically dispersed anterior pituitary cells : functional validation of a method. Endocrinology 91, 562. 